\title{
情報共有
}

\section{II ．企業内の情報共有とグループウェアの動向}

キーワード

マルチメディア, グループウェア, ネットワーク, 情報共有,

プロトコル, ワークフロー

1.はじめに

80 年代初頭に起こった OA（Office Automation）ブー ムは, 特にホワイトカラーの業務効率化, 生産性向上への 気運を盛り上げ，情報システムの高度化を促した。現在で は，業務改革やBPR (Business Process Reengineering）などの言葉を変えた形で，当時と同様の議論が行わ れ，システム構築が進められている。

しかし，10数年前の OA が时ばれたころと現在とは， 様々な点で事情が大きく異なる。それを最も端的に表わし ているのが・グループウェア’なる用語の出現である。 80 年代OAによって導入され一部普及したサービスは，ワ 一ドプロセシングや帳票処理, 簡単な文書ファイリング, 電子メールなどであり，個人作業（デスクワーク）の支援 にとどまっていた。90年代に入って登場したのがグルー プウェア，すなわちコミュニケーションを通した人と人と のグループ協同作業支援の考え方である（図 1) (1) (4)。

本稿では，今後のオフィスミドルウェアの中核となるグ ループウェア，およびグループウェアシステムの基本要件 である（主として企業内を対象とした）情報共有に関する 技術動向妾，システム事例を交えて述べる。

\section{2. グループウェアと情報共有のとらえ方}

グループウェアあるいはほほ同義で用いられる CSCW (Computer Supported Cooperative Work) なる用語は, 85 年ごろに米国で初めて情報システム分野で使われるよ うになった。その後, 89 年ごろから日本でもよく使われ るようになり，一つの技術あるいはサービスの分野として 定着してきた。用語としてのグループウェアに関しては, 89 年に, C. A. Ellis（元. Xerox PARC）が与えた「共通 の仕事や目的をもって働くユーザグループを支援し，協同 作業環境へのインタフェースを提供するコンピュータベー スのシステム」が一般的な定義としてよく引用される(4)。

米国でその概念が提唱されて約 10 年が経った現在，広

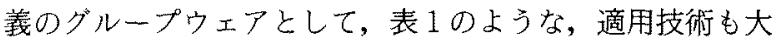
きく異なる2つの側面が認識されるようになった

II. Information Sharing and Group Ware for Enter prise Networks, By Siro Sakata. Member (NEC Coporation)
正員 阪田史 郎 日本電気 (株) C\&C 研究所

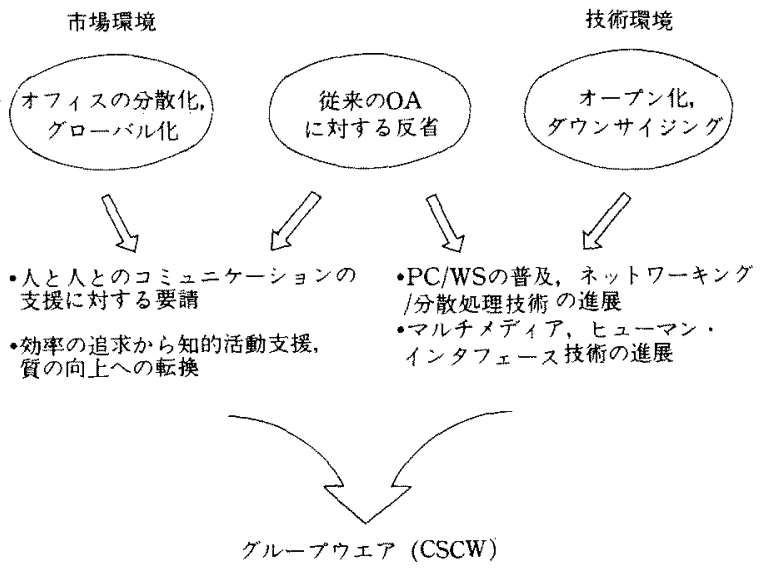

図 1 グループウェアの背景

表 1 グループウェアの2つの側面

\begin{tabular}{|c|c|c|}
\hline & リアルタイム通信型 & 蓄 \\
\hline 概 要 & $\begin{array}{l}\text { ・マルチメディア分散会議, } \\
\text { プレゼンデーション } \\
\cdot \text { アブリケーション分散㙝調 }\end{array}$ & $\begin{array}{l}\cdot \text { ワータフロー } \\
\text { コンピェーティング }\end{array}$ \\
\hline 技術 & $\begin{array}{l}\text { ・マルチメディア } \\
\text { ・コンピュータとの通信の融 } \\
\text { 合 }\end{array}$ & $\begin{array}{l}\text { ・オブジェクト指向 } \\
\text { (エージェント) } \\
\text { ・通信の既存の電子メール }\end{array}$ \\
\hline 目 & $\begin{array}{l}\text { ・新しい付加価値, 㤂用領域 } \\
\text { 開拓 } \\
\text { (遠隔保守, 協同デザイン, } \\
\text { ソフト笄発, 教育・トレー } \\
\text { ニング, 医撩等) }\end{array}$ & $\begin{array}{l}\text { ・オフィス業務效率化, 生産 } \\
\text { 性向上 } \\
\text { (統合文書管理,プロジェク } \\
\text { 卜管理等) } \\
\text { ·BPRツッール }\end{array}$ \\
\hline
\end{tabular}

例. MERMAID (NEC)

一つは，マルチメディアのコンピュータと通信の技術を駆 使したリアルタイム通信型のグループウェア，もう一つ は，電子メールをベースとしワークフローコンピューティ ングと呼ばれる蓄積型のグループウェアである。リアルタ イム通信型のグループウェアは，マルチメディアグループ ウェアとも呼びうる。

リアルタイム通信型のグループウェアは, 動画や音声を 含むマルチメディアの情報を遠隔の複数の利用者の間で双 方向同時に交換し共有する機能を提供する。face-to-face にできるだけ近い通信環境の実現により，遠隔地にいる複 
数の人達の間の臨場感ある直接的な協同作業を支援するこ とを歁とている。一方の蓄積型のグループウェアは, 文書データベース（あるいはファイル）の統合管理と電子 メールによる帳票の自動転送・回覽を基本機能とし, ワー プロなどの文書処理, スケジュール管理, 帳票処理, 文書 ファイリングなどの各種ツールソフトの統合も重要な要素 となる。10数年前ブームとなった OAのころに叫ばれた 統合OAの狙いとほぼ同じであり，ソフトウェア技術や $\mathrm{AI}$ 技術がベースとなる。

リアルタイム通信型のグループウェアがマルチメディア 情報のインタラクションにより，直接的にグループ協同作 業を支援するのに対し，蓄積型のグループウェアは個人作 業支援とグループ協同作業の双方を総合的に支援しようと する，あるいは技術的には個人作業支援の延長線上にある (図2)。

以上の $2 つ の$ 側面を情報共有の視点からとらえると，り アルタイム通信型は同時 (同期型) 共有, 蓄積型は非同時 (非同期型) 共有ということができる。リアルタイム通信 型の情報同時共有は会議型の利用形態であるため技術内容 も理解しやすいが，蓄積型の情報非同時共有については， グループウェアの枠を越えた極めて広い意味をも含みう る(8) (10)。データベースやファイルを介して集中/分散のい ずれかの形態で情報を管理するシステムは，利用者間での 何らかの情報非同時共有を可能にする, あるいはそのため のメカニズムをもつ。従来のメインフレームで利用されて きた基幹業務用のデータベースをはじめ, 電子メールの一 形態である電子揭示板, 部門内で共通に利用する文書ファ イル,さらに, インターネットの WWW (World Wide Web）はハイパーテキスト構造のファイルを世界中に分

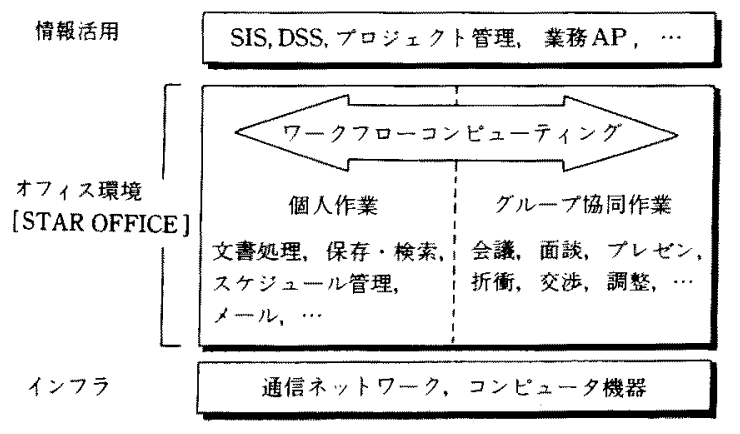

図 2 情報活動からみたグループウェア
散させ科学者の間での情報非同時共有を可能见する目的で 作られたシステムであり，Intermedia("1) は協同文書作成， IBIS (Issue Based Information Systems) ${ }^{(12)}$ 恃議論のモ デルに基づく意思決定支援を目的として，情報非同時共有 の機構が組み込まれたシステムである。

本稿では，情報非同時共有についてはグループウェアの 中での議諭としてワークフローシステム(ワークフローコ ンピューティング技術が適用されたシステム）に関連する 動向について述べる。

\section{3. マルチメディアグループウェアにおける情報共 有（情報の同時共有）}

一般に分散環境における情報の共有には，表 2 と図 3 に 示す 3 つのレバルが考党られる。この中で，蓄積データの 共有は非同時共有に相当し，同時性に関連するのはビュー の共有と処理結果の共有である(8).(9)。このビューの共有と 処理結果の共有は，協調作業空間の共有ということもで き，そこでは複数の利用者に提示される情報が時時刻刻同 一であることを保証することが要求される（一貫性の保 証)。

3.1 同時参照のためのグループ調整・排他制御：ビュー の共有

マルチメディア会議システムなどのりアルタイム型のグ ループウェアに枕ける, 共有情報へのアクセス（書き込み や編集）に関する排他制御が代表例である。各卫ーザのデ イスプレイ画面やウィンドウ上の情報の同一性を保つこと は，ユーザ全員で共通の目的をもって協同作業するときの

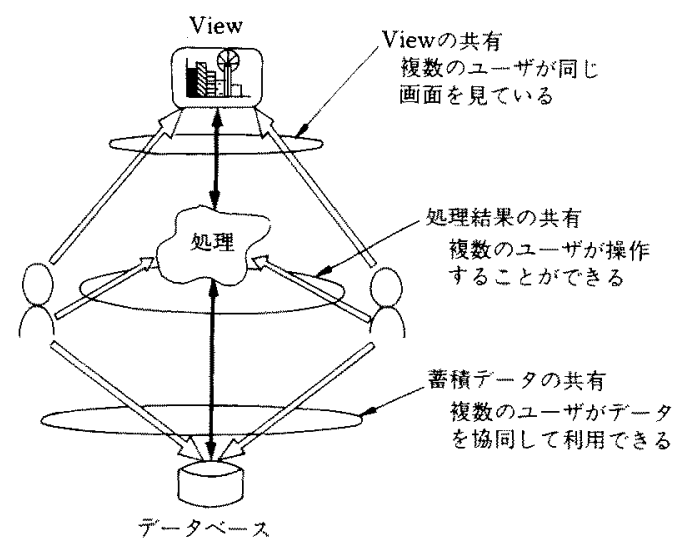

図 3 情報共有に関する三つのレベル

表 2 情報共有に関する三つのレベル

\begin{tabular}{|c|c|}
\hline ビューの共崔 & 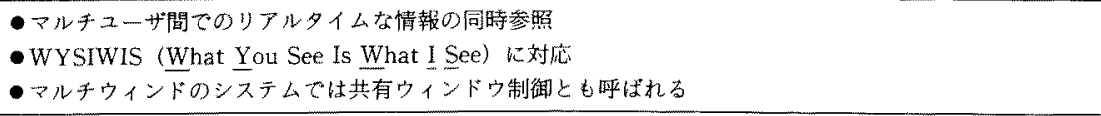 \\
\hline 起理結果の共有 & 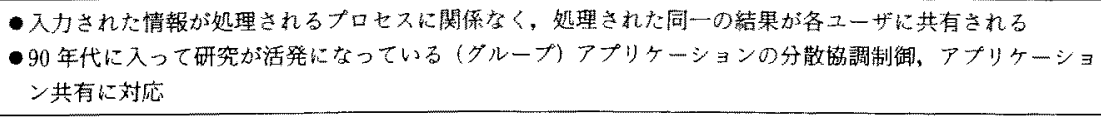 \\
\hline 蓄積データの共有 & 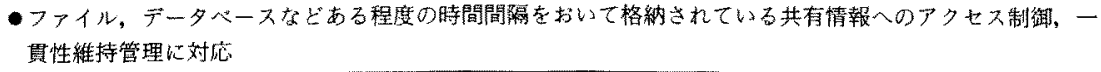 \\
\hline
\end{tabular}


表 3 アプリケーション共有制御に関する分散方式と集中方式の比較

\begin{tabular}{|c|c|c|c|c|}
\hline & 方 & 䦎 要 & 所 & 短 \\
\hline $\begin{array}{l}\text { 分散方式 } \\
\text { (重複) }\end{array}$ & $\frac{i}{\frac{1}{\text { APS }}}$ & $\begin{array}{l}\text { - 処理指示が闹報 } \\
\text { さ扎各WS 上の } \\
\text { AP で奏行 } \\
\text { …. } \\
\text { 処理指示 }\end{array}$ & $\begin{array}{l}\text { ・処理指示のみがWS 間で送受信さ } \\
\text { れるのて、ネットワータ・トラフィ } \\
\text { ックが小さい } \\
\text { ・実行結果を自WSの AP から受け } \\
\text { 取るので応答時間が短い }\end{array}$ & 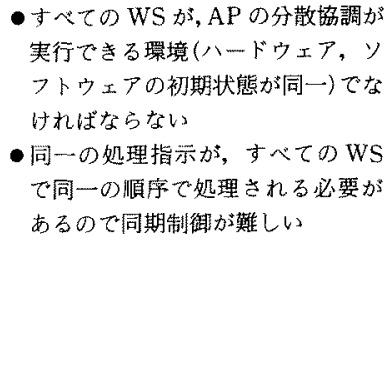 \\
\hline 集中方式 & $\underbrace{\frac{\mathrm{c}}{\mathrm{A}}}_{\frac{\mathrm{AP}}{\mathrm{AP}}}$ & $\begin{array}{l}\text {-つのWSの } \\
\text { APて実行し, } \\
\text { その結果 (デー } \\
\text { 夕本体) を同報 } \\
\text { — } \\
\text { 実行結果 }\end{array}$ & $\begin{array}{l}\text { - 各WS に実行結果が同報されるの } \\
\text { で,APの同期制御が容易 }\end{array}$ & 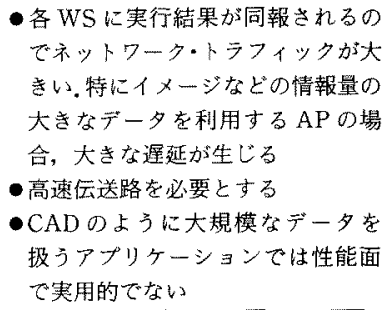 \\
\hline
\end{tabular}

必須機能である。最近, 参照情報が結果として同時に共有 されるこのような機能を，白板共有と呼ばれるようになっ ている。

このレベルの共有制御では, 排他制御の単位とアクセス 権の移動方法が重要となる。排他制御の単位については, ある時点での操作対象の情報（文書など）全体, 特定のウ インドウ内の表示情報全体, 特定の情報単位（例えばイメ ージスキャナからの入力情報, スプレッドシートに扔ける 特定の行・カラム位置など) などが考えられる。この単位 を細かくすればするほど操作が複雑になり，ヒューマンイ ンタフェース上問題となる。アクセス権の移動方法につい ては, 集中制御, 要求順, バトン型などの様々な形態が検 討され，評価されている(13) 亿15)。

\section{2 アプリケーションの共有制御：処理結果の共有}

広く解釈するとビューの共有も含みうるが，一般的に は,ビューの共有のみでは会議など使い方が限定されるの に対し，処理結果の共有では会議に相当する機能を使った 会議の上位に位置づけられる多様なアプリケーションが協 調的に動作できるように支援することが目的となる。

アプリケーションを共有するとは，グループ協同作業に おいて，ある参加者がアプリケーションに対して何らかの 入力をしたときに，その入力に対する実行結果を参加者全 員がリアルタイムに得ることができることをいう。一つの 文書を何人か協同で同時に編集したり，一つのスプレッド シートを協同で作成・修正（再計算）したりするときに必 要となる機能である。

アプリケーション共有方式には，分散（または重複）方 式と集中方式がある。分散方式では,アプリターションを 各端末で起動し, 入力をすべての端末に分配し, 実行は各 端末でローカルに行う。集中方式では, アプリケーション を一つの端末で起動し実行 (出力) 結果を各端末に同報す
る。表 3 に両方式の定性的な比較を示す ${ }^{(8),(9)}$ 。

WS（UNIX）においては，実用化された分散方式とし ては日本電気の MERMAID が代表例である。集中方式と してはXウィンドウを対象としたXTV, SharedXなど がフリーソフトウェアとして利用可能となっている。

PC (Windowsなど) については，実装が容易な，排他 制御を行わない, アプリケーション共有も集中方式のみの 製品が出現しつつある。

\section{4. マルチメディアグループウェアシステムの事例}

MERMAID (Multimedia Environment for Remote Multiple-Attendee Interactive Decision-making) 日本電気(株)C\&C 研究所に抢いて，マルチメディア通信 技術を駆使したグループウェアのプラットフォームとし て，88年に世界に先駆けて開発，実用化されたシステム である(13)-(17)。

遠隔地の複数人が自席のWS/PCを利用して, 会議を はじめとする様々なグループ協同作業を行うことができ る。ISDNやATM，専用線，インターネットなどを自由 に組み合わせて, 文字, 図形, イメージ, 手書き情報に加 え，音声と動画，すなわちあらゆるメディアの情報を同時 に交換し，参加者全員で共有し協調しながら処理すること ができる。特に，ATM を利用した場合は高速高品質のマ ルチメディアの交換による協同作業が可能となっている。

すでに川崎, 筑波, 東京, 大阪，神戸，広島，札幌，福 岡などの拠点, さらには米国（プリンストン，サシノゼ）, シンガポール，ドイツ（ボン）など国内外の 30 地点以上 を結び，国境を超え時差を超えて 8 年以上の間，技術討議 や遠隔講義, 分散シミュレーション, 分散協同ソフトウェ ア開発などに利用されてきた。大学や官公庁，製造，金融 業などの一般ユーザにも 1500 台以上のシステムが導入, 


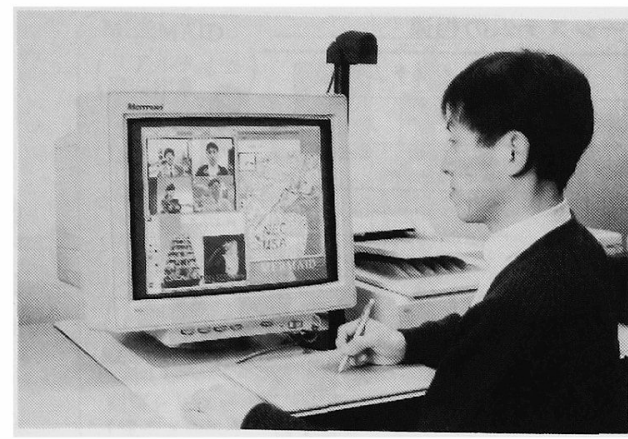

図 4 MERMAID を米国とシンガポールと日本(東京, 大阪)の 3 力国 4 地点を同時に結んで利用している様 子

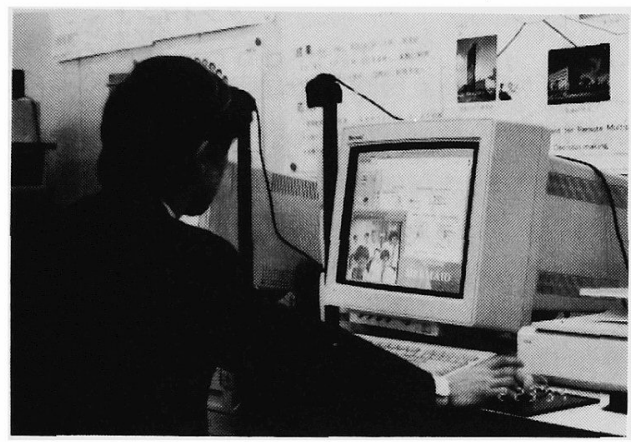

図 5 MERMAIDを利用して日本からシンガポールに 遠隔講義をしている様子

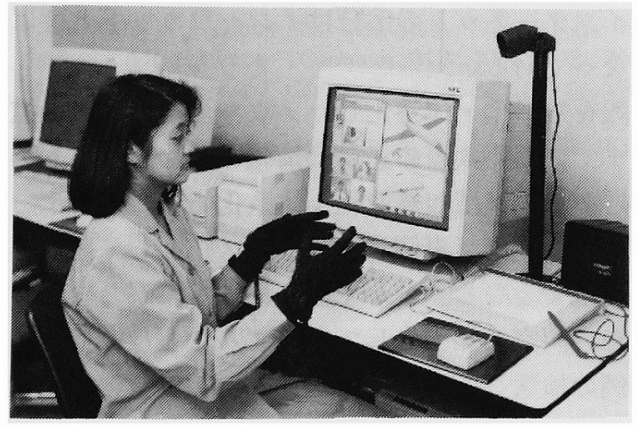

図 6 MERMAIDのアプリケーション共有機能を利用 して，遠隔の 4 人による協同デザイン(仮想現実感)を 行っている様子

利用されている。図 4 は, MERMAID を米国とシンガポ ールと日本（東京と大阪）の 3 国の 4 人を同時に結んで利 用している時の様子，図 5 は，日本からシンガポールの大 学の先生や学生に対し遠隔講義をしている様子を示す。

また，MERMAID は集中型・分散型双方のアプリケー ション共有機能も実現している。図 6 は, MERMAID を 使って遠隔の 4 人が仮想現実感（VR）をアプリケーショ ンとする協同デザインを行っている様子を示す。

以下に，MERMAID 利用事例を紹介する。

（1）大学間，国際間を含む遠隔講義

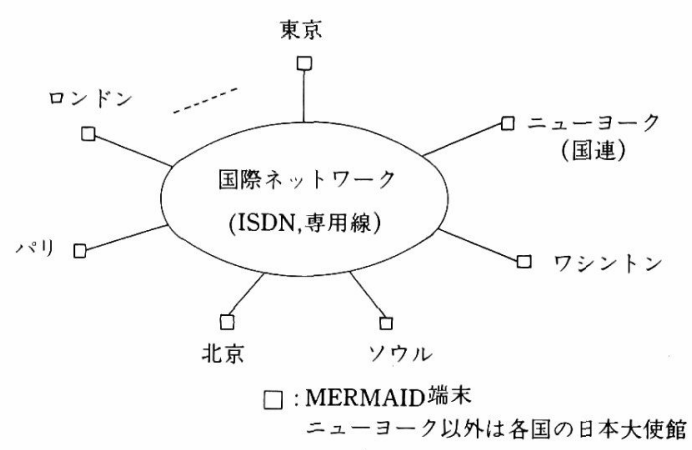

図 7 大使や外交官に国際ホットラインとして利用さ れている MERMAID

学内での先生の自席からの講義やゼミ指導のほかに, 異 なる大学間での講義, たとえば東京の大学の先生が九州の 別の大学の学生に講義をすることも行われている。海外の 大学にも導入され, 国際レベルでの遠隔講義も行われている。

（2）世界各国の日本大使館を結ぶ国際ホットライン

多地点間，国際間での典型的事例である。ニューヨーク の国連やワシントン，ロンドン，パリ，北京，ソウル，東 京などの各日本大使館に MERMAID 端末を設置し，外交 官のための国際ホットラインとしての利用がある（図 7)。 95 年 1 月に発生した阪神大震災の際には, 各国の大使館 間で同時の情報交換が行われただけでなく, 被災状況など の日本からの情報が現地に住む日本人にマルチメディアで リアルタイムに伝えられ，大いに活用された。

（3）遠隔保守

全国の各保守拠点に MERMAID 端末を設置し，保守要 員への遠隔教育・訓練や, 保守拠点と保守現場を結んだ遠 隔保守・障害診断業務に適用している例がある。最前線の 保守員と高度な技術力・専門知識を有する後方の技術部員 とが, その場で議論し迅速な協同分析が行えるため, 障害 対応に要する時間が従来の $1 / 5$ 以下に短縮されている。

\section{5． ワークフローシステムにおける情報共有（情報 の非同時共有)}

従来のメインフレームを主体としたデータベースと，ワ ークフローシステムとの主な相違を表 4 に示す。ワークフ ローシステムで分散型が中心となった理由は，利用者間で 共有したい情報の量が一般文書を含むため格段に多くなり 集中型では負荷が集中しすぎる, LAN・パソコンの普及や 電子メールの浸透により情報を分散して管理することが容 易になった，ということが挙げられる。

情報の共有を前提とした分散管理においては，従来より 互いに関連する, トランザクションにおける並行（同時更 新）制御，版管理，アクセス制御が技術課題となってい る(10)。アクセス制御については，ワークフローシステム においても, 従来のデータベースと同様, 利用者職位や特 性（プロジェクトのメンバか否かなど）に応じて，アクセ スできる情報やその権限（読み出しか書き込みかなど）を 


\begin{tabular}{|c|c|c|}
\hline & 従来のデータベース & ワークフローシステム \\
\hline 情報の種類 & 数值データが主 & 文辢情報 \\
\hline 対象業務 & 定型業務 & 定型栄務十半定型業務 \\
\hline 利用者 & 各業務アプリケーション担当者 & 一般オフイスワーカ \\
\hline $\begin{array}{l}\text { 共有情報 } 0 \\
\text { 筙津 }\end{array}$ & 各業務アプリケーション巣位 & $\begin{array}{l}\text { 業船アプリケーションに閣じない一般文 } \\
\text { 畫が主 }\end{array}$ \\
\hline $\begin{array}{l}\text { 霄報の管理 } \\
\text { 形態 }\end{array}$ & 集中型が主 & 分散型 \\
\hline $\begin{array}{l}\text { 情報へのア } \\
\text { クセス形態 }\end{array}$ & $\begin{array}{l}\text { 並行制御により共有情報へのアクセスを } \\
\text { 利用者毎に独立して行っているように見 } \\
\text { せかける }\end{array}$ & $\begin{array}{l}\text { 別の人と情報を共有していることを各利 } \\
\text { 用者に意識させる }\end{array}$ \\
\hline
\end{tabular}

区別する形で行的れる。並行制御と版管理についても，ワ ークフローシステムは各サイトのサーバごとに個別に赛行 される。しかし, 所望の情報が遠隔のサ一バにある場合に は, 広域のネットワークを通して転送する必要があり，そ の通信速度が遅い場合はアクセス時間がかかる。このた め, サーバ間で一日や一週間のようにある程度の長さの一 定期間ごとにコピーを送り合う、レプリケーション（情報 同期）を実行することが一般的になりつつある。このレプ リケーションの機能がワークフローシステムの特徴であ $\eta$, Lotus 社の Notesや Microsoft 社の Exchangeなど の蓄積型のグループウェア製品では利用可能となっている (図 8$)^{(18)}$ 。

レプリターションを行う場合は, 各サイトのサーバの情 報を同一に保つための排他制御が必要となる。しかし，こ の排他制御に対しては, 70 年代より分散データベースに おるる同時更新制御，情報一貫性の維持の問題として盛ん に研究がなされたが，いまだに完全な解は得られておら ず，実用に供している例も少ない。さらにレプリケーシ ヨンに扔ける通信トラフィックは無視できず頻繁にレプリ ケーションを実行することはできない。排他制御との両立 を含めたレプリケーションの効率的な方式が, ワークフロ ーシステムの重要課題となっている。

このほかに, 情報共有に関連するワークフローシステム の課題としては,以下が挙げられる。

・RDB (関係データベース) と文書との統合

RDBから検索された数值デー夕を文畫の中に反映させ たり，逆に作成した報告文書の中の数值デー夕を新たな管 理情報としてRDBに更新して格納したりするため, 共通 つアクセスインタフェースの設定や双方の間の情報変換が 必要となる。

\section{・インターネットとの連携}

インターネットはその生立ちからボトムアップでオープ ンという, 企業内の基幹業務システムとは正反対の過程を 圣て実現されてきた。しかし，WWWの出現以来, 情報 発信も含めた文書作成や登録，そこへのアクセスが著しく 容易になり，企業内の基幹業務としても一部利用され始め ている。これまで企業内での情報共有を主眼に置いて発展
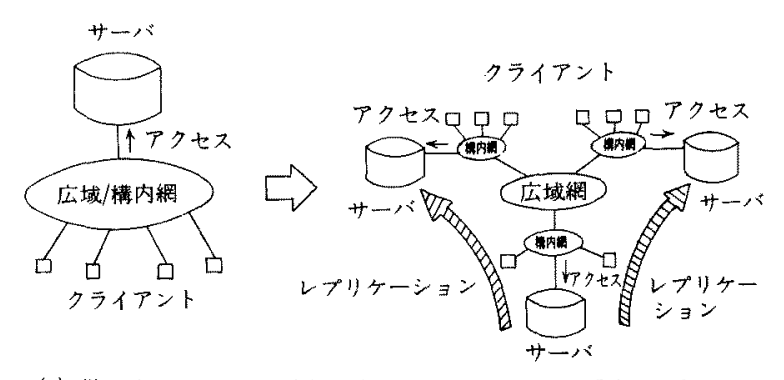

(a) 単・サーパへの

(b) 分散サーバへのローカルアクセスと レプリケーションによるサーハ間情報同期

図 8 ワークフローシステムにおけるレプリケーション

してきたグループウェアに扔いても，企業間のコミュニケ ーションを組み込む形でのインターネットとの連携が必要 になってくると思われる。このような企業内での利用に特 化したインターネットの部分はイントウネットと呼ばれる ようになっている。

・情報を知識化・体系化したノウハウベースへの抬張

これまでの情報共有の議論は情報の断片を扱うものであ つたが, それを集積し構造化・体系化することによって知 識さらにノウハウ（事例データベース）として記録してお くことが重要となる。とかく個人に埋もれがちな経験や， ウハウを専門家の知識として共有することは, 過去の類似 した事例の検索などにも効果があり，より質の高い情報再 利用を促進する。

\section{6.おわりに}

企業内における情報共有とグループウェアに関し，共有 に関する同時/非同時の分類に基づいて，その技術動向と 課題を述べた。双方に共通の以下の課題を克服しながら， より知的で効果的な情報活用に発展していくことが期待さ れる。

（1）同時共有と非同時共有のシームレスな統合

蓄積型のグループウェアとリアルタイム通信型のグルー プウェアの統合ということになるが, 例えば図 9 のよう に, ソフトウェアの開発プロジェクトに扔いて突発的に仕 様変更が発生したときに，ワークフローの中でリアルタイ ム通信と電子メールを併用して効率的に対処するようなこ 


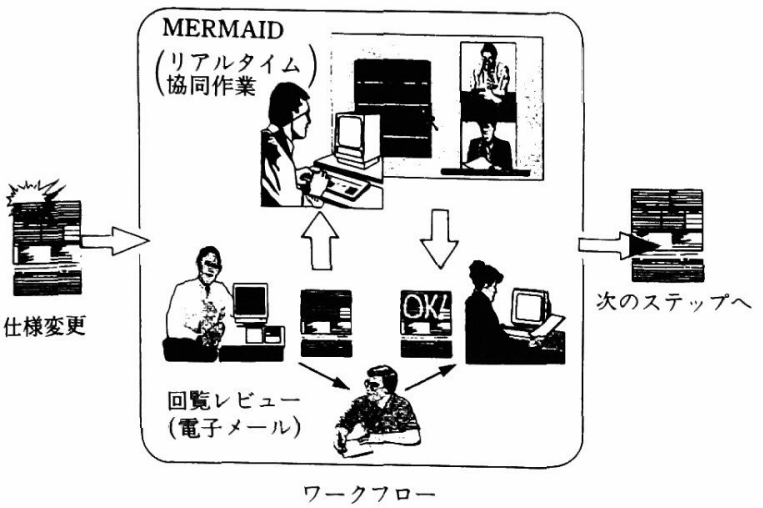

図 9 統合グループウェアシステム

とが必要となる(19)。

（2）モバイル環境における情報共有

無線通信と携帯端末を用いた環境において，会議を招集 して情報交換・共有したり, 遠隔地にあるファイルにアク セスしたりすることを可能にすることにより，いつでもど こでも誰とでも何人とでも, 容易にグループワークを実現 する環境の提供が要求される。

(平成 7 年 12 月 13 日受付)

\section{文献}

（1）阪田：「マルチメディアとネットワークによるグループウェア の実現技術」，ソフト・リサーチ・センター(1992)。

（2）阪田, 他：「マルチメディアとB-ISDN 時代のグループウェ ア」，オーム社 (1993)。

（3）阪田，他：「マルチメディアシステム」，昭晃堂 (1995)。

(4) C. A. Ellis, S. J. Gibbs and G. L. Rein: "Groupware-Some Issues and Experiences", Commun. ACM, 34, 1, p. 39 (1991. 1)

（5）阪田：「マルチメディア C\&C 技術の将来展望」, 第 18 回末来医 学会, p. 18 (1995.1)。

（6）阪田：「2010 年のマルチメディアシステム」, 情報処理学会誌, 36, 9, p. 836 (1995.9)

（7）阪田：「ネットワークとマルチメディア」, 平成 7 年電気・情報 連合大会予稿集 (1995.8)。

(8) 阪田：「グループウェアのためのマルチメディアコンピューテ イングとマルチメディアネットワーク」, 情報処理学会誌, 34, 8, p. $994(1993.8)$ 。
（9）阪田：「グループウェアから見たフレキシブルネットワーク」, 電子情報通信学会誌, 77, 4, p. 384 (1994.4)。

（10）村永・守安：「グループワークのための情報共有技術」，情報処 理学会誌, 34, 8, p. 1006 (1993.8)。

(11) K. E. Smith and S. B. Zdonik: "Intermedia, A Case Study of the Differences between Relational and Object-Oriented Database Systems", OOPSLA 87, p. 452 (1987).

(12) G. L. Rein and C. A. Ellis: "rIBIS, A Group Hypertext System", Computer Supported Cooperative Work and Groupware, Academic Press, p. 223 (1991)

（13）阪田・福岡, 他：「マルチメティィア分散在席会議システム MER MAIDーグループウェアのプラットフォーム」, 情報処理学会論 文誌，32，8，p. $1200(1991.8) 。$

(14) S. Sakata: "Multimedia and Multi-party Desktop Conference System (MERMAID) as Groupware Platform", IFIP Congress 94, p. 63 (1994, 9).

(15) S. Sakata, H. Fukuoka et al.: "Distributed Multimedia and Multi-party Desktop Conference System-Platform for Groupware", Proc. CSCW, p. 27 (1990. 10)

(16) 阿部, 前野, 阪田：「マルチメディア分散在席会議システム (MERMAID) を利用したグループアプリケーションの分散協 調制御方式の提案」, 情報処理学会論文誌, 34, 6, p 1406 (1993.6)。

(17）阪田：「NECのマルチメディアグループウェアへの取組み」, 研究開発マネジメント, 4, 7, p. 30 (1994.7)。

（18）河井, 土屋：「情報共有の空が開く, 本格化するグループワー ク」, 日経コミュニケーション, p. 58 (1995.5)。

（19）垂水：「グループウェアのソフトウェア開発への応用」，情報処 理学会誌, 33, 1, p.22 (1992.12)。

阪 田 史 郎 (正員) 昭和 49 年早稲田大学理工学部電子通信

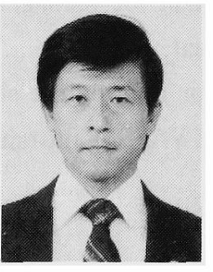
学科大学院修士課程修了。同年日本電気(株)入 社。以来, コンピュータネットワークアーキテ クチャ, 分散処理, プロトコル, マルチメディ ア情報通信, グループウェアなどコンピュータ と通信の統合領域 $(C \& C)$ に関連する研究開発 に従事。工学博士。著書「マルチメディアとネ ットワークによるグループウェアの実現技術」 (ソフトリサーチセンター)，共著「マルチメディア情報通信」「マ ルチメディア時代のグループウェア」「図解グループウェア」(以 上, オーム社),「B-ISDN の基盤技術」(ソアライズ社), 「マルチ メディアシステム」(昭晃堂) ほか多数。現在同社 C\&C 研究所夕ー ミナルシステム研究部部長。IEEE, 電子情報通信学会, 情報処理学 会会員。 